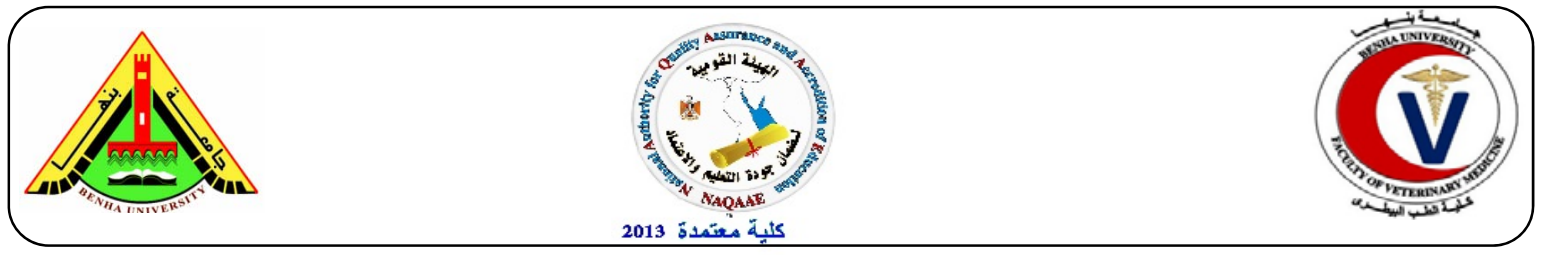

\title{
Biochemical Effect of Experimental Hepatic Failure in Tissues Antioxidants in Aging Rats
}

\author{
Hussein Abd EI - Maksoud ${ }^{1}$; Usama Mahrous ${ }^{2}$; Qadri Mohammed Sadik ${ }^{3}$ and Yaser M. Abdel - \\ Nabi $^{3}$ \\ ${ }^{1}$ Biochemistry Dep. Fac. of Vet. Med. Benha University. ${ }^{2}$ Animal Husbandry Dep. Fac. of Vet. Med. \\ Damnhour University. ${ }^{3}$ Biochemistry Dep. Fac. of Vet. Med. Damnhour University
}

\section{A B S T R A C T}

The present study aimed to trigger the effect of experimentally induced chronic hepatic failure on tissues antioxidant status in different ages the hepatic failure induced by Intraperitoneal administration of Thioacetamide at a dose of $(30-\mathrm{mg} / \mathrm{kg}$ body weight) four times through two months with 15 days interval Rats were sacrificed $24 \mathrm{hrs}$ after the last dose of TAA the recorded data revealed significant decrease in Brain tissue Monoaminooxidase (MAO) and significant increase in brain tissue nitric oxide (NO) and ammonia, significant decrease in Brain, kidney, muscles and hepatic tissues Reduced Glutathione (GSH) Superoxide Dismutase (SOD) and Glutathione Peroxidase (GPX) from the recorded results it could be concluded that hepatic failure is a hazard stress in tissues antioxidants in different ages

Keywords: Hepatic failure, Thioacetamide and tissues antioxidants.

(http://www.bvmj.bu.edu.eg)

(BVMJ-29(2): 161-169, 2015)

\section{INTRODUCTION}

$\mathrm{L}$ iver is the second largest organ (the first largest organ is the skin) in the human body. The structural organization of the liver reflects its role as a guardian against foreign chemicals entering the systemic circulation. It is the first organ contacted with entirely absorbed nutrients and xenobiotics via the portal vein and plays a central role in whole body nitrogen metabolism and the metabolic elimination of most drugs and other foreign compounds, thus making it an important target for toxicity (Abdel-Maksoud 2011). Hepatic toxicity as a result of drugs and environmental toxins represents a wide spectrum of diseases. The great susceptibility of the liver to damage by chemical agents appears to be a consequence of its primary role in the metabolism and disposition of foreign substances (Marzouk 2012). Aging significantly decreased levels of the antioxidant enzymes as super oxide dismutase (SOD) and concurrent treatment with alpha lipoic acid significantly reversed the oxidative effects related to aging (Joachim, et al (2011). High levels of ammonia accumulating as a result of hepatic dysfunction are thought to be the chief causative factor for HF Nevertheless, the role of other factors like Mercaptans, altered amino acid profiles, short chain fatty acids and false neurotransmitters cannot be ruled out (kumar et al., 2007). Reactive oxygen species are thought to play a vital role in the pathogenesis of hepatic encephalopathy. Oxidative stress has also been implicated in liver dysfunction caused by various other factors like acetaminophen overdose, hemochromatosis, alcoholic liver injury, toxin exposures, viral hepatitis and in neurodegenerative diseases like AIDSDementia, Huntington Chorea, Schizophrenia, Parkinson's disease, etc 
(Cirico and Omaye 2010). Thioacetamide (TAA) is one of the most potent hepatotoxicants frequently used for experimental purposes which produces centrilobular necrosis after a single dose administration. In spite of the fact that oxidative stress seems to play a very important role in the mechanism of TAAinduced injury Staňková et al., (2010).

This study aims to elucidate the putative effects of acute liver failure, induced by intraperitoneal administration of Thioacetamide, on Brain, muscles, heart and Liver tissues of different Ages rats

\section{MATERIALS AND METHODS}

\subsection{Animals and experimental design}

Eighty male albino rats were used in the present experiment and divided in to eight groups according to age each one includes ten rats: Group (1): (one-month-old) control. Group (2): (one -month-old) administered Thioacetamide at a dose of (30 - $\mathrm{mg} / \mathrm{kg}$ body weight) through intraperitoneal route (i.p.) four times through two months with 15 days' interval for induction of chronic hepatic failure. Rats were sacrificed $24 \mathrm{hrs}$ after the Last dose of TAA. Group (3): (6-month-old) control. Group (4): (6-month-old) administered Thioacetamide at a dose of (30 - $\mathrm{mg} / \mathrm{kg}$ body weight) through intraperitoneal route (i.p.) four times through two months with 15 days interval for induction of chronic hepatic failure. Rats were sacrificed $24 \mathrm{hrs}$ after the Last dose of TAA. Group (5): (12-month-old) control. Group (6): (12-month-old) administered Thioacetamide at a dose of (30 - $\mathrm{mg} / \mathrm{kg}$ body weight) through intraperitoneal route (i.p.) four times through two months with 15 days interval for induction of chronic hepatic failure. Rats were sacrificed $24 \mathrm{hrs}$ after the Last dose of TAA. Group (7): (24-month-old) rats control. Group (8): (24-month-old) administered Thioacetamide at a dose of (30 - $\mathrm{mg} / \mathrm{kg}$ body weight) through intraperitoneal route (i.p.) four times through two months with 15 days interval for induction of chronic hepatic failure. Rats were sacrificed $24 \mathrm{hrs}$ after the Last dose of TAA.

\subsection{The Evaluated blood biochemical, parameters}

Brain, muscles, heart and Liver Levels of Antioxidant enzymes: Superoxide Dismutase (SOD) Johansson and Borg (1988) Glutathione Peroxidase (GPx) (Chiu et al., 1976). Reduced Glutathione (GSH). (Bauer,1982). Brain samples alone were analyzed for determination of:

Brain ammonia by (Searcy, et al 1967). Monoamine Oxidase (MAO) by (DenBlawen, et al. 1983). Nitric Oxide (NO) Montgomery and Dymock, (1961).

\section{RESULTS}

\subsection{Brain tissue Mono Amino Oxidase (MAO):}

The recorded data in Table (1) and Figure (1) showed that the experimental hepatic failure induced a significant decrease in brain tissue MAO in all ages which was at its maximum decrease in the $12^{\text {th }}$ month old rats and at its lowest decrease in the $2^{\text {nd }}$ month old ones in comparison with its control values.

\subsection{Brain Tissue Nitric Oxide (NO) and Ammonia}

The recorded data in Table (1) and Figure (1) showed that the experimental hepatic failure induced a significant increase in brain tissue. NO and ammonia in all ages which was at its maximum increase in the $24^{\text {th }}$ month old rats and at its lowest increase in the $2^{\text {nd }}$ month old ones in comparison with its control values.

\subsection{Tissues Reduced Glutathione (GSH):}

The recorded data in Table (2) and Figure (2) showed that the experimental hepatic failure induced a significant decrease in Brain, kidney, muscles and hepatic tissues GSH in all stages which was at its maximum decrease in the $4^{\text {th }}$ month old rats and at its lowest decrease in the $24^{\text {th }}$ month 
old ones in comparison with its control values.

\subsection{Tissues Super Oxide Dismutase (SOD):}

The recorded data in Table (3) and Figure (3) showed that the experimental hepatic failure induced a significant decrease in Brain, kidney, liver, and muscle tissue SOD in all stages which was at its maximum decrease in the $2^{\text {nd }}$ month old rats and at its lowest decrease in the $12^{\text {th }}$ month old ones in comparison with its control values.

\subsection{Tissue Glutathione Peroxidase (GPX):}

The recorded data in table (4) and fig. (4) showed that the experimental hepatic failure induced a significant decrease in brain, kidney, muscles and liver tissues GPX in all stages which was at its maximum decrease in the $4^{\text {th }}$ month old rats and at its lowest decrease in the $2^{\text {nd }}$ month old ones in comparison with its control values.

Table (1): Effect of liver failure on MAO, NO and Ammonia in Brain tissue of rats

\begin{tabular}{lllll}
\hline $\begin{array}{l}\text { Item } \\
\text { Treatment }\end{array}$ & & Monoamino oxidase & Nitric oxide & Ammonia \\
\hline Health & & $266.05 \pm 11.36^{\mathrm{a}}$ & $34.10 \pm 1.59^{\mathrm{b}}$ & $67.55 \pm 12.92^{\mathrm{b}}$ \\
$\begin{array}{l}\text { Failure } \\
\text { Treatment*time }\end{array}$ & $129.19 \pm 8.30^{\mathrm{b}}$ & $100.14 \pm 5.28^{\mathrm{a}}$ & $152.69 \pm 46.73^{\mathrm{a}}$ \\
\multirow{2}{*}{$2^{\text {nd }}$ month } & Health & $198.92 \pm 10.12^{\mathrm{c}}$ & $26.08 \pm 1.52^{\mathrm{e}}$ & $59.71 \pm 9.87^{\mathrm{e}}$ \\
& Failure & $102.22 \pm 5.34^{\mathrm{d}}$ & $69.14 \pm 3.52^{\mathrm{c}}$ & $103.74 \pm 14.34^{\mathrm{d}}$ \\
$4^{\text {th }}$ month & Health & $227.70 \pm 11.90^{\mathrm{c}}$ & $29.35 \pm 1.53^{\mathrm{e}}$ & $62.74 \pm 10.36^{\mathrm{e}}$ \\
& Failure & $103.86 \pm 11.66^{\mathrm{d}}$ & $77.92 \pm 4.07^{\mathrm{c}}$ & $126.50 \pm 20.91^{\mathrm{c}}$ \\
\multirow{2}{*}{$12^{\text {th }}$ month } & Health & $292.47 \pm 15.29^{\mathrm{b}}$ & $33.40 \pm 1.75^{\mathrm{e}}$ & $69.83 \pm 11.54^{\mathrm{e}}$ \\
& Failure & $104.24 \pm 5.45^{\mathrm{d}}$ & $112.83 \pm 6.17^{\mathrm{b}}$ & $179.12 \pm 29.60^{\mathrm{b}}$ \\
\multirow{2}{*}{$24^{\text {th }}$ month } & Health & $345.09 \pm 18.04^{\mathrm{a}}$ & $47.56 \pm 2.49^{\mathrm{d}}$ & $77.92 \pm 12.88^{\mathrm{e}}$ \\
& Failure & $206.45 \pm 10.79^{\mathrm{c}}$ & $140.67 \pm 7.35^{\mathrm{a}}$ & $201.39 \pm 33.28^{\mathrm{a}}$ \\
\hline
\end{tabular}

Table (2): Effect of liver failure on GSH level

\begin{tabular}{|c|c|c|c|c|c|}
\hline \multicolumn{2}{|l|}{$\begin{array}{l}\text { Item } \\
\text { Treatment }\end{array}$} & Brain & Kidney & Muscle & Liver \\
\hline \multicolumn{2}{|l|}{ Health } & $67.76 \pm 20.02^{\mathrm{a}}$ & $89.81 \pm 25.11^{\mathrm{a}}$ & $82.16 \pm 29.87^{\mathrm{a}}$ & $41.36 \pm 19.35^{\mathrm{a}}$ \\
\hline \multicolumn{2}{|l|}{ Failure } & $37.70 \pm 18.16^{\mathrm{b}}$ & $46.69 \pm 17.14^{b}$ & $36.75 \pm 20.09^{\mathrm{b}}$ & $20.80 \pm 15.28^{b}$ \\
\hline \multicolumn{6}{|c|}{ Treatment*time } \\
\hline \multirow{2}{*}{$2^{\text {nd }}$ month } & Health & $83.99 \pm 13.89^{\mathrm{a}}$ & $103.21 \pm 15.01^{\mathrm{a}}$ & $113.15 \pm 20.96^{\mathrm{a}}$ & $69.53 \pm 8.51^{\mathrm{a}}$ \\
\hline & Failure & $60.72 \pm 10.04^{\mathrm{b}}$ & $58.24 \pm 9.09^{c}$ & $65.16 \pm 11.38^{\mathrm{c}}$ & $41.55 \pm 16.46^{\mathrm{b}}$ \\
\hline \multirow{2}{*}{$4^{\text {th }}$ month } & Health & $79.00 \pm 13.25^{\mathrm{a}}$ & $111.33 \pm 18.41^{\mathrm{a}}$ & $98.72 \pm 15.78^{b}$ & $43.78 \pm 7.44^{b}$ \\
\hline & Failure & $45.54 \pm 7.53^{\mathrm{c}}$ & $61.73 \pm 10.20^{c}$ & $41.25 \pm 7.19^{\mathrm{d}}$ & $20.26 \pm 3.33^{\mathrm{d}}$ \\
\hline \multirow{2}{*}{$12^{\text {th }}$ month } & Health & $66.56 \pm 10.94^{\mathrm{b}}$ & $87.03 \pm 14.38^{\mathrm{b}}$ & $71.42 \pm 11.84^{\mathrm{c}}$ & $30.23 \pm 4.34^{\mathrm{c}}$ \\
\hline & Failure & $27.32 \pm 4.52^{\mathrm{d}}$ & $43.52 \pm 7.19^{\mathrm{d}}$ & $23.58 \pm 4.15^{\mathrm{e}}$ & $11.85 \pm 4.35^{\mathrm{c}}$ \\
\hline \multirow{2}{*}{$24^{\text {th }}$ month } & Health & $41.49 \pm 6.86^{\mathrm{c}}$ & $57.68 \pm 9.53^{\mathrm{c}}$ & $45.36 \pm 5.68^{d}$ & $21.91 \pm 5.51^{\mathrm{d}}$ \\
\hline & Failure & $17.20 \pm 2.84^{\mathrm{d}}$ & $23.28 \pm 3.85^{\mathrm{e}}$ & $17.02 \pm 2.37^{\mathrm{c}}$ & $9.53 \pm 1.60^{\mathrm{e}}$ \\
\hline
\end{tabular}

Mean within the same column carry different superscripts are significantly different. 
Table (3): Effect of Hepatic failure on SOD level

\begin{tabular}{llllll}
\hline $\begin{array}{l}\text { Item } \\
\text { Treatment }\end{array}$ & & Brain & Kidney & Muscle & Liver \\
\hline $\begin{array}{l}\text { Health } \\
\text { Failure }\end{array}$ & & $57.51 \pm 21.40^{\mathrm{a}}$ & $45.49 \pm 12.70^{\mathrm{a}}$ & $96.76 \pm 23.06^{\mathrm{a}}$ & $128.76 \pm 40.63^{\mathrm{a}}$ \\
\multicolumn{2}{l}{ Treatment*time } & $29.85 \pm 14.75^{\mathrm{b}}$ & $27.13 \pm 12.95^{\mathrm{b}}$ & $54.91 \pm 34.73^{\mathrm{b}}$ & $48.47 \pm 15.76^{\mathrm{b}}$ \\
$2^{\text {nd }}$ month & Health & $86.02 \pm 14.22^{\mathrm{a}}$ & $51.61 \pm 8.53^{\mathrm{a}}$ & $121.08 \pm 19.80^{\mathrm{a}}$ & $171.97 \pm 31.62^{\mathrm{a}}$ \\
& Failure & $49.59 \pm 8.20^{\mathrm{c}}$ & $39.47 \pm 6.52^{\mathrm{b}}$ & $74.65 \pm 13.07^{\mathrm{cd}}$ & $67.80 \pm 11.21^{\mathrm{d}}$ \\
$4^{\text {th }}$ month & Health & $61.73 \pm 10.20^{\mathrm{b}}$ & $57.49 \pm 10.87^{\mathrm{a}}$ & $103.23 \pm 17.06^{\mathrm{ab}}$ & $146.74 \pm 24.25^{\mathrm{b}}$ \\
& Failure & $30.36 \pm 5.02^{\mathrm{d}}$ & $37.67 \pm 6.28^{\mathrm{bc}}$ & $62.66 \pm 10.47^{\mathrm{de}}$ & $51.64 \pm 8.57^{\mathrm{e}}$ \\
\multirow{2}{*}{$12^{\text {th }}$ month } & Health & $46.55 \pm 7.69^{\mathrm{c}}$ & $41.00 \pm 6.88^{\mathrm{b}}$ & $88.41 \pm 11.99^{\mathrm{bc}}$ & $113.34 \pm 18.73^{\mathrm{c}}$ \\
& Failure & $28.34 \pm 4.68^{\mathrm{d}}$ & $20.24 \pm 3.35^{\mathrm{d}}$ & $41.44 \pm 5.11^{\mathrm{e}}$ & $43.52 \pm 7.19^{\mathrm{ef}}$ \\
$24^{\text {th }}$ month & Health & $35.75 \pm 6.11^{\mathrm{d}}$ & $31.87 \pm 5.54^{\mathrm{c}}$ & $74.31 \pm 11.66^{\mathrm{cd}}$ & $82.98 \pm 13.71^{\mathrm{d}}$ \\
& Failure & $11.13 \pm 1.84^{\mathrm{e}}$ & $11.13 \pm 1.84^{\mathrm{e}}$ & $40.89 \pm 63.25^{\mathrm{e}}$ & $30.91 \pm 5.36^{\mathrm{f}}$ \\
\hline
\end{tabular}

Mean within the same column carry different superscripts are significantly different.

Table (4): Effect of liver failure on GPX level

\begin{tabular}{|c|c|c|c|c|c|}
\hline \multicolumn{2}{|l|}{$\begin{array}{l}\text { Item } \\
\text { Treatment }\end{array}$} & Brain & Kidney & Muscle & Liver \\
\hline \multicolumn{2}{|l|}{ Health } & $76.66 \pm 26.29^{\mathrm{a}}$ & $102.64 \pm 38.38^{\mathrm{a}}$ & $133.90 \pm 31.65^{\mathrm{a}}$ & $243.09 \pm 56.15^{\mathrm{a}}$ \\
\hline \multicolumn{2}{|c|}{$\begin{array}{l}\text { Failure } \\
\text { Treatment*time }\end{array}$} & $46.81 \pm 22.66^{b}$ & $59.90 \pm 24.79^{\mathrm{b}}$ & $79.86 \pm 31.42^{b}$ & $137.63 \pm 41.71^{b}$ \\
\hline \multirow{2}{*}{$2^{\text {nd }}$ month } & Health & $96.30 \pm 34.08^{\mathrm{a}}$ & $118.81 \pm 42.56^{\mathrm{a}}$ & $171.70 \pm 28.23^{\mathrm{a}}$ & $274.19 \pm 43.36^{\mathrm{a}}$ \\
\hline & Failure & $76.91 \pm 12.71^{\mathrm{bc}}$ & $89.73 \pm 12.63^{b}$ & $118.66 \pm 19.12^{c}$ & $184.19 \pm 30.44^{b}$ \\
\hline \multirow{2}{*}{$4^{\text {th }}$ month } & Health & $90.07 \pm 14.89^{a b}$ & $129.31 \pm 37.61^{\mathrm{a}}$ & $138.29 \pm 18.70^{b}$ & $264.13 \pm 43.65^{\mathrm{a}}$ \\
\hline & Failure & $51.61 \pm 8.53^{\mathrm{d}}$ & $67.80 \pm 11.21^{\mathrm{c}}$ & $90.07 \pm 14.89^{\mathrm{d}}$ & $151.80 \pm 25.09^{\mathrm{bc}}$ \\
\hline \multirow{2}{*}{$12^{\text {th }}$ month } & Health & $67.80 \pm 11.21^{\mathrm{c}}$ & $97.13 \pm 15.95^{b}$ & $117.04 \pm 18.20^{\mathrm{c}}$ & $249.03 \pm 59.86^{\mathrm{a}}$ \\
\hline & Failure & $39.47 \pm 6.52^{\mathrm{d}}$ & $54.05 \pm 11.43^{\mathrm{c}}$ & $69.22 \pm 9.66^{\mathrm{e}}$ & $124.48 \pm 20.57^{\mathrm{c}}$ \\
\hline \multirow{2}{*}{$24^{\text {th }}$ month } & Health & $52.46 \pm 10.93^{\mathrm{d}}$ & $65.33 \pm 15.52^{c}$ & $108.58 \pm 15.01^{\mathrm{c}}$ & $185.00 \pm 30.64^{\mathrm{b}}$ \\
\hline & Failure & $19.23 \pm 3.18^{\mathrm{e}}$ & $28.03 \pm 4.78^{\mathrm{a}}$ & $41.49 \pm 6.86^{\mathrm{f}}$ & $90.07 \pm 14.89^{\mathrm{d}}$ \\
\hline
\end{tabular}

Mean within the same column carry different superscripts are significantly different.

\section{Discussion}

The recorded in data (Table 1) showed that brain MAO activity was very highly significantly increased in aged rats these results are in accordance with those recorded by Wang et al (2012) who noticed that, an increased MAO-B activity in brain tissues were recorded in old mice (24 months) than in young mice (1 month). Moreover, Egashira (2000) investigated the effects of breeding conditions on MAO activity in aged rat brains and recorded that, in the forebrain of aged rats the increases of MAO activity were observed in the aggregated aged rats as compared to the individual aged rats. The recorded increase in brain MAO activity might be due to age- related increase in the rate of mitochondrial $\mathrm{O}_{2}{ }^{-}$and $\mathrm{H}_{2} \mathrm{O}_{2}$ generation and huge amounts of oxidative damage leading to several neurodegenerative disorders, due to an imbalance between free radical generation and antioxidant defense system Sandhu and Kaur (2002). In addition, the age- dependent increase in $\mathrm{H}_{2} \mathrm{O}_{2}$ generation was fully related to the MAOA isoform but not by the MAO-B in the aging process (Volchegorskii et al. (2001), and the increased concentration of otherwise unchanged extra synaptosomal MAO-B (Oreland and Gottfries 1986). These results were nearly similar to the reported studies of Bruck et al. (2004) who evaluated the effect of TAA on hepatic and brain NO level and revealed a significant increase in its concentration in TAA treated rats other than control normal group. 
Moreover, Huang et al., (2007) recorded a significant increase in brain NO level in TAA treated rats when compared to control normal rats. Similarly, Shaker et al. (2011) observed that brain NO contents were also found to be elevated significantly in rats intoxicated with TAA, compared with the control group. NO is a signaling molecule that plays a key role in the pathogenesis of inflammation and it is overproduced in abnormal physiological conditions. Physiological amounts of NO acts on different energy linked and metabolic mitochondrial pathways while relatively higher concentrations of NO deplete cellular GSH by conjugating with $\mathrm{NO}$ to form an S-nitroso-glutathione adduct (Gong et al., 2010). The influences of nitric oxide (NO) on hepatic and brain injury are controversial, mainly derived from its diverse functions: NO may be protective or toxic at various concentrations, and its synthesis by NO synthase (NOS) is under delicate control. Regarding the influences on the brain, NO may be implicated in vascular and blood-brain barrier permeability regulation. It contributes to hemodynamic changes in the brain and also to the pathogenesis of acute hepatic failure related cerebral edema (Huang et al., 2012) These results were nearly similar to the reported studies of Ahmed et al. (2004) who recorded a significant increase in plasma ammonia level in rats treated with TAA. Also Fadillioglu et al. (2010) found that blood ammonia level was higher in TAA induced HE group than those of control group. During hepatic inadequacy, as occurs in FHF, large quantities of ammonia in the portal blood escapes the detoxification process and enters systemic circulation. Thus, blood and tissue (brain) ammonia levels are elevated rapidly in FHF (Reddy et al., 2004). After TAA injection, the blood ammonia level was increased significantly in comparison with the control groups (Fadillioglu et al., 2010). TAA is metabolized by hepatic cytochrome P4502E1 to more toxic products: Thioacetamide sulfoxide (TAASO) and
thioacetamide-S,S-dioxide (TAASO2) to initiate hepatocellular necrosis with ROS (Jaeschke et al., 2002). TAA treatment of rats is characterized by marked elevation in plasma and brain ammonia levels. The hyperammonemic state prevailing during TAA treatment may by itself lead to impairment of antioxidant enzyme functions as shown by (Kosenko et al., 2003) in vivo by administration of ammonium acetate. Consistent with this (Murthy et al., 2000) have showed in vitro exposure of cells to antioxidant enzymes resulted in the suppression of ammoniainduced swelling. Further, studies of (Norenberg, 1998) also have shown that the free radicals may contribute to the cell swelling. A relationship between oxidative stress and hyperammonemia has been well established and evidences point out that hyperammonemia can be induced partly via oxidative stress-mediated lipid peroxidation (Vidhya and Subramanian, 2003). According to (Fadillioglu et al., 2010) there have been two ways to prevent HE: through prevention of ROS injury and decreasing blood ammonia level. The obtained data demonstrated in Table $(2,3$, and 4) revealed that, administration of TAA to normal rats exhibited a significant reduction in liver and brain SOD, GPx, activities and GSH level, observed $24 \mathrm{hrs}$ after induction of AHF when compared with control normal and other protected groups. These results similar to the recorded results of Sarkar and Sil (2007) showed that treatment of normal rats with TAA, caused a significant reduction in liver GPx, SOD and CAT activities and GSH level, as compared to only saline treated control group. Furthermore, Baskaran et al. (2010) observed that the activities of SOD, CAT, GPx and GSH contents in liver tissue homogenate were decreased significantly in TAA-administered rats, in relation to control rats. Also, Shaker et al. (2011) observed that hepatic SOD, GPx, CAT and GSH contents of TAA treated rats were significantly reduced due to TAAintoxication when compared with the 
control group. Higher pro-oxidant liver status in rats with TAA is likely to involve a high consumption of cellular and circulate antioxidants. This could be partly related to the decrease in the liver activity of CAT, GSH and GPx, otherwise lowering ROS. However, an important compensatory mechanism like is the up-regulation of SOD activity, is developed by the liver. It could indicate an activation of cellular defense mechanisms in order to protect the hepatocytes from harmful consequences caused by oxidative stress (Ramanathan et al., 2002). Mn-SOD is an important mitochondrial antioxidant enzyme and its activity in the present study was lowered after inducing FHF. (Kosenko et al., 2003) also reported decreased Mn-SOD activity after the injection of ammonium acetate which creates acute toxicity. Generation of a large amount of ROS due to TAA can overwhelm the antioxidant defense mechanism and damage cellular ingredients such as lipids, proteins and DNA; this in turn can impair cellular structure and function (Ansil et al., 2011). Further, GPx catalyzes the GSH dependent reduction of $\mathrm{H}_{2} \mathrm{O}_{2}$ and other peroxides and protects the organism from oxidative damage (Lauterburg, 2002). Indeed, the prooxidant/antioxidant balance has been observed to change on the behalf of oxidation, as TAA administration resulted in liver GSH levels and activities of SOD and GSH-Px to be significantly decreased (Aydin et al., 2010). Decreased enzymatic activities of GPx, CAT and SOD activity observed in the present study might lead to elevated levels of $\mathrm{H}_{2} \mathrm{O}_{2}$. This could lead to oxidative stress in the mitochondria of FHF rats. Similar observations have been made by (Dogru-Abbasoglu et al., 2001) in the liver during Thioacetamide-induced hepatic failure. Oxidative stress has been shown to cause mitochondrial dysfunction which is implicated in many neurological disorders (Paradies et al., 2013). Furthermore, brain is rich in polyunsaturated fatty acids and possesses high content of iron in certain areas, which is supposed to promote free radical production. Added to this, brain has low levels of antioxidant enzymes, low repair mechanisms and non-explicative neuronal cells (Kulbhushan et al., 2008). All the aforesaid factors play a critical role in balancing the damaging effects and the antioxidant defenses (Reddy et al., 2004). The toxicity of TAA results from its bioactivities in the liver to reactive metabolites, causing the production of ROS responsible for oxidative stress (Paradies et al., 2013). These events are followed by glutathione depletion, a reduction in $\mathrm{SH}$ thiol groups and oxidation of cell macromolecules, including lipids (Sanz et al., 2002). Our results are in agreement with these findings. TAA also produced oxidative stress by depleting the GSH level suggesting the presence of free radicals generated by TAA. The antioxidant enzymes (CAT, SOD and GST) assays showed that TAA treatment caused the depletion of these enzymes; therefore, it could be said that TAA caused the cellular damage by inhibiting the activity of the antioxidant enzymes (Sarkar and Sil, 2007). Thus, GSH inhibition in HE would increase the susceptibility of plasma membranes towards peroxide attacks. The loss of GSH and formation of protein-glutathione mixed disulfide (PrSSG) in the brain results to various membrane dysfunctions, such as inhibition of $\mathrm{Na}^{+} \mathrm{K}^{+}$-ATPase activity (Khan et al., 2009). From the recorded results it could be concluded that hepatic failure is a hazard stress in tissues antioxidants in different ages

\section{REFERENCES}

Abdel-Maksoud H.A 2011. Short notes in Biochemical alterations in Hepatic and Renal Diseases. In Bostan ElMaerifa Press. 1:2011.

Ahmad, A., Pillai, K.K., Najmi, A.K., Ahmad, S.J., Pal, S.N. and Balani, D.K. 2004. Evaluation of hepatoprotective potential of jigrine post-treatment against thioacetamide 
induced hepatic damage. J. Ethno. Pharmacol., 79:35-41.

Ansil, P.N.; Nitha, A.; Prabha, S.P.; Wills, P.J.; Jazaira, V. and Latha, M.S. 2011. Protective effect of Amorphophallus campanulatus (Roxb.) Blume. tuber against thioacetamide induced oxidative stress in rats. Asian Pacific. J. Tropical Medicine, 870-877

Aydın, F., Kusku-Kiraz, Z.; Semra, D.; Mine, G.; Mujdat, U.; Necla, K. and Ak-Toker, 2010. Effect of carnosine against thioacetamide-induced liver cirrhosis in rat. Peptides, 31:67-71.

Baskaran, Y.; Periyasamy, V. and Venkatraman, A.C. 2010. Investigation of antioxidant, antiinflammatory and DNA-protective properties of eugenol in thioacetamide-induced liver injury in rats. Toxicology, 268:204-212

Bauer, J.D. 1982. Clinic laboratory methods. $9^{\text {th }}$ Ed: 555, the C.V. company, Westline Industrial Missouri.

Bruck, R.; Aeed, H.; Avni, Y.; Shirin, H.; Matas, Z.; Shahmurov, M.; et al. 2004. Melatonin inhibits nuclear kappa B activation and oxidative stress and protects against thioacetamide induced liver damage in rats. Hepatol., 40(1):86-93.

Chiu, D.; Staults, F. and Tappal, L. 1976. Purifcation and properties of rat lung soluble glutathione peroxidase. Bioch. Biophys. Acta. 445:558-566.

Cirico TL, Omaye ST. 2010. Additive or synergetic effects of phenolic compounds on human low density lipoprotein oxidation. Food Chem Toxicol 44:510-6.

Den-Blawen, D.H., Poppe, W.A. and Trischler, W., 1983. Determination of MAO. J.Clin. Chem. Biochem. 21:381-386.

Doğru-Abbasoğlu, S.; Kanbağlı, Ö.; Balkan, J.; Çevikbas, U.; AykaçToker, G. and Uysal, M. 2001. The protective effect of taurine against thioacetamide hepatotoxicity of rats. Human Exp. Toxicol., 20:23-27.

Egashira, T. 2000. Effects of aging on monoamine oxidase activity of mouse and rabbit rissues. Nippon Ronen Igakkai, Zasski, 37(3):233-238.

Fadillioglu, E.; Gursul, C. and Iraz, M. 2010. Effects of caffeic acid phenethyl ester on thioacetamideinduced hepatic encephalopathy in rats. Progress in NeuroPsychopharmacology and Biological Psychiatry, 34:1440-1445.

Gong, G.; Qin, Y.; Huang, W.; Zhou, S.; Yang, X. and Li, D. 2010. Rutin inhibits hydrogen peroxide-induced apoptosis through regulating reactive oxygen species mediated mitochondrial dysfunction pathway in human umbilical vein endothelial cells. Eur. J. Pharmacol., 628:27-35.

Huang, G.; Besner, G.E. and Brigstock, D.R. 2012. Heparin-binding epidermal growth factor-like growth factor suppresses experimental liver fibrosis in mice. Lab. Invest., 92: 703-712.

Jaeschke, H.; Gores, G.J.; Cederbaum, A.I.; Hinson, J.A.; Pessayre, D. and Lemasters, J.J. 2002. Mechanisms of hepatotoxicity. Toxicol. Sci., 65: 166-176.

Joachim, P., Joon, H., Srikumar, C. and Nagaraja, H. 2011. Hepatoprotective effects of alpha lipoic acid on aginginduced oxidative stress in the rat liver. Cell \& Bioscience. 12:11861197

Khan, M.M.; Ahmad, A.; Ishrat, T.; Khuwaja, G.; et al. 2009. Rutin protects the neural damage induced by transient focal ischemia in rats. Brain Research 1292: 123-135.

Kosenko, E.; Venediktova, N.; Kaminsky, Y.; Montoliu, C. and Felipo, V. 2003. ): Sources of oxygen radicals in brain in acute ammonia intoxication in vivo. Brain Res., 981:193-200.

Kulbhushan, T.; Anupama, T.; Idrish, Y.A.; Jeena, G. and Anil, B.G. 2008. Tannic 
acid prevents azidothymidine (AZT)

induced hepatotoxicity and genotoxicity along with change in expression of PARG and histone H3 acetylation Toxicology Letters 177: 90-96.

Kumar, A., Naidu, P.S., Seghal, N., Padi, S.S., 2007. Neuroprotective effects of resveratrol against intra-cerebroventricular colchicine-induced cognitive impairment and oxidative stress in rats. Pharmacology 79:17-26

Lauterburg, B.H. 2002. Analgesics and glutathione. Am. Ther., 9(3):225233.

Marzouk, M 2012. Biochemical effect of certain antioxidants on oxidative stress and mitochondrial dysfunction in brain of experimentally induced hepatic failure in rats. Msc. Vet. Asc. Fac. Vet. Med. Benha Univ.

Montgomery, H. and Dymock, F. 1961. The determination of nitrite in water. Analyst, 16:414-417.

Murthy, C.R.K.; Bai, G.; Dombro, R.S. and Norenberg, M.D. 2000. Ammonia induced swelling in primary cultures of rat astrocytes: role of free radicals. Soc. Neurosci. Abstr., 26:1892.

Johansson LH, Borg LAH. 1988. A spectrophotometric method for determination of SOD activity in small tissue samples. Anal Biochem 174:331-336.

Norenberg, M.D. 1998. Astroglial dysfunction in hepatic encephalopathy, Metab. Brain Dis., 13:319-335.

Oreland, L. and Gottfries, C.G. 1986. Brain and brain monoamine oxidase in aging and in dementia of Alzheimer's type. Prog. Neuro-psychopharmacol. Biol. Psychiatry, 10(3-5):533-540.

Paradies, G.; Pestrosillo, G.; Pistolese, M. and Ruggiero, F.M. 2013. Reactive oxygen species generated by the mitochondrial respiratory chain affect the complex III activity via cardiolipin peroxidation in beef heart sub mitochondrial particles. Mitochondrion, 1: 151-159.

Ramanathan, K.; Balakumar, B.S. and Panneerselvam, C. 2002. Effects of ascorbic acid and a-tocopherol on arsenic-induced oxidative stress. Human Experimental Toxicology, 21:675-680.

Reddy, P.V.; Murthy, Ch.R. and Reddanna, P. 2004. Fulminant hepatic failure induced oxidative stress in nonsynaptic mitochondria of cerebral cortex in rats. Neurosci. Lett., 368: 15-20.

Reitman, A. and Frankel, S. 1957. ReitmanFrankel colorimetric method of GOT/AST and GPT/ALT Transaminases. Amer J. Clin. Path., 28:56-63

Sanz, N.; Diez-Fernandez, C.; Andres, D. and Cascales, M. 2002. Hepatotoxicity and aging: endogenous antioxidant systems in hepatocytes from 2-, 6-, 12-, 18- and 30-month-old rats following a necrogenic dose of thioacetamide. Biochim. Biophy. Acta, 87: 12-20.

Sarkar, M.K. and Sil, P.C. 2007. Hepatocytes are protected by herb Phyllanthus niruri protein isolate against thioacetamide toxicity. Pathophysiology, 14:113-120.

Searcy, R.L., Reardon, J.E., Foreman, J.A. and Amer, J. 1967. Chemical method for determination of Ammonia. Med. Techn., 33:15-20.

Shaker, M.E.; Shiha, G.E.; Tarek M. and Ibrahim, T.M. 2011. Comparison of early treatment with low doses of nilotinib, imatinib and a clinically relevant dose of silymarin in thioacetamide-induced liver fibrosis. Eur. J. Pharmacol., 670: 593-600.

Staňková, P, Kučera, O, Lotková, H, Roušar, T, Endlicher, R, Červinková. $Z$, 2010. The toxic effect of thioacetamide on rat liver in vitro Toxicology in Vitro 24:2097-2103

Voitenko, N.N. 2001. Brain monoamine oxidase in prematurely aging OXYS 
rats. Vopr. Med. Kim., 47(6):582587.

Voitenko, N.N. and Popova, N.K. 1991. Brain monoamine oxidase during aging. Vopr. Med. Kim., 37(4):28-31.

Volchegorskii, I.A.; Teleshova, I.B. and Turygin, V.V. 2003. Comparative study of age-related activity of monoamine oxidase- $\mathrm{B}$, antioxidant defense enzymes, and tolerance to oxidative stress in various segments of human spinal cord

Vidhya, M. and Subramanian, P. 2003. Enhancement of circulatory antioxidants by alpha- ketoglutarate during sodium valproate treatment in Westar rats. Pol. J. Pharmacol., 55: 31-36.

Wang, M.E.; Chen, Y.C.; Chen, I.S.; Hsieh, S.C.; Chen, S.S. and Chiu, C.H. 2012. Curcumin protects against Thioacetamide-induced hepatic fibrosis by attenuating the inflammatory response and inducing apoptosis of damaged hepatocytes. Journal of Nutritional Biochemistry (2012) 